\title{
Akut spinal kord yaralanması sonrası erken cerrahi dekompresyonun korpus kavernozum ve motor fonksiyon üzerine olan etkilerinin araştırılması
}

\section{Evaluation of corpus cavernosum and motor function after early surgical decompressssion on acute spinal cord injury}

\author{
Zekeriya Öztemür*, Gündüz Tezeren, Nedim Durmuş, İhsan Bağcıvan, \\ Bülent Saraç, Hayati Öztürk, Okay Bulut
}

Ortopedi ve Travmatoloji Anabilim Dalı (Yrd. Doç. Dr. Z. Öztemür, Prof. Dr. G. Tezeren, Doç. Dr. H. Öztürk, Prof. Dr. O. Bulut), Farmakloji Anabilim Dalı (Prof. Dr. İ. Bağcıvan, Doç. Dr. B. Saraç), Cumhuriyet Üniversitesi Tıp Fakültesi, TR-58140 Sivas, Risk Yönetimi Daire Başkanlığı, Farmakovijilans Risk Yönetimi Birimi (Dr. N. Durmuş), Sağlık Bakanlığı İlaç ve Tıbbi Cihaz Kurumu, TR-06520 Ankara

\section{Özet}

Amaç. Akut spinal kord yaralanması sonrasi erken cerrahi dekompresyonun korpus kavernozum ve motor fonksiyon üzerine olan etkilerinin araştırılması. Yöntem. Yirmi bir adet 9-12 aylık Yeni Zelanda tipi, erişkin erkek tavşan kullanıldı. Denekler kontrol grubu $(\mathrm{n}=5)$, laminektomi grubu $(\mathrm{n}=6), 15$ saniye kompresyon grubu $(\mathrm{n}=5)$ ve 60 sn kompresyon grubu $(\mathrm{n}=5)$ olmak üzere 4 gruba ayrıldı. Laminektomi grubuna sadece laminektomi işlemi yapıldı. Kompresyon gruplarına $60 \mathrm{~g}$ kapama gücü olan anevrizma klipsi ile 15 ve 60 saniye kompresyon uygulandı. 1, 3, 5 ve 7 . günler Modifiye Tarlov skoru ile motor değerlendirme yapıldı. 7 gün sonunda bütün denekler sakrifiye edilerek spinal kordlarından histopatolojik çalıșma ile beraber izole korpus kavernozum dokularından in vitro organ banyosunda kasılma ve gevșeme yanıtları incelendi. Bulgular. Modifiye Tarlov skoruna bakıldığında gruplar arası fark anlamlı bulundu $(\mathrm{p}<0,05)$. Korpus kavernozum karbakol ile gevşeme yanıtlarına bakıldığında 15 ve 60 sn'lik kompresyonlu grupta maksimum gevşeme yanıtları istatistiksel olarak benzer idi ve bu gruplardaki maksimum gevșeme yanıtları gerek kontrol gerekse laminektomili gruba göre anlamlı oranda azalmıștı $(\mathrm{p}<0,05)$ Laminektomili ve kontrol grupları karşılaştırıldığında maksimum gevşeme yanıtları arasında anlamlı fark bulunmadı $(\mathrm{p}>0,05)$. Her 4 grupta da $\mathrm{pD} 2$ değerleri benzerdi $(\mathrm{p}>0,05)$. Sonuç. Akut spinal kord yaralanmasında erken cerrahi dekompresyonun etkinliğini araștırdığımız bu model ile spinal kord yaralanmasında seksüel disfonksiyonunun tedavisinde kullanılması düşünülen ilaçların in vitro ortamda ayrıntılı olarak araştırılması mümkün olabilir. Akut spinal kord yaralanmasında erken cerrahi dekompresyon motor iyileşme yönünden faydalı olabilir ve korpus kavernozum fonksiyonları açısından olumlu etkiler yapabilir. Ayrıca, akut spinal kord yaralanması geçiren hastalarda erektil disfonksiyon fosfodiesteraz tip V inhibitörleri ile çözülebilir.

Anahtar sözcükler: Spinal kord yaralanması, erken dekompresyon, korpus kavernozum

\begin{abstract}
Aim. Evaluation of corpus cavernosum and motor function after early surgical decompressssion on acute spinal cord injury. Method. We initiated the study with $21 \mathrm{New}$ Zealand male rabbit. The animals were assigned to four groups which were sham group $(n=6)$, laminectomy group $(n=5), 15$ seconds compression group $(\mathrm{n}=5)$ and 60 seconds compression group $(\mathrm{n}=5)$. Fifteen seconds or 60 seconds compression applied to compression group in 60 gram compression force with aneurysm clips. We evaluated motor system with modified Tarlov score at 1st, 3rd, 5th and 7th days of cord injury. All rabbits are sacrificed after 7 day postoperatively. Histopathological evaluations are made on spinal cord and in vitro relaxation and contraction tests were performed on urinary bladder and corpus cavernosum tissues in tissue baths. Results. There was significant difference between all groups according modified Tarlov score $(p<0.05)$. Maximum relaxation response of the corpus cavernosum with carbachol was similar between 15 seconds compression group and 60
\end{abstract}


seconds compression group and maximum relaxation response of the corpus cavernosum with carbachol decreased in compression group compared with laminectomy and sham groups $(\mathrm{p}<0.05)$. pD2 values were similar in four groups $(\mathrm{p}>0.05)$. Conclusion. The model used in this study showing the efficacy of early surgical decompression in acute spinal cord injury may be useful to investigate the effects of agents for sexual dysfunction in vitro. Early surgical decompression may develop the motor and corpus cavernosum functions after acute spinal cord injury. In addition, phosphodiesterases type $\mathrm{V}$ inhibitors may be useful for treating erectile dysfunction in spinal cord injured patients.

Keywords: Spinal cord injury, early decompression surgery, corpus cavernosum

Geliş tarihi/Received: 20 Kasım 2012; Kabul tarihi/Accepted: 05 Mart 2013

\section{*İletişim adresi:}

Dr. Zekeriya Öztemür, Ortopedi ve Travmatoloji Anabilim Dalı, Cumhuriyet Üniversitesi Tıp Fakültesi, TR-58140 Sivas. E-posta: oztemurz@gmail.com

\section{Giriş}

Travmatik spinal kord yaralanmaları, spinal kord dokularının kaybına ve kalıcı nörolojik kayıplara yol açar. Bu tip hastaların yarısında yaralanma tam değildir ve bazı rezidüel fonksiyonlar kalır [1, 2]. Vertebral fraktür veya dislokasyon, spinal kord zedelenmesi veya kontüzyonunun sıklıkla görülen sebebidir [1, 3]. Spinal kord birçok nöron ve çeşitli biyolojik sistemleri kontrol ettiği için, spinal kord yaralanması sonrasında bir çok sistemde bozukluklar meydana gelebilmektedir $[4,5]$.

Akut spinal kord yaralanmasında (ASKY) birincil yaralanmayı izleyen ve karmaşık olayları içeren ikincil yaralanma da bulunur. İkincil yaralanmanın altta yatan nedenleri iskemi, intraselüler asidoz, $\mathrm{Ca}+2$ iyon konsantrasyonundaki değişimler, sitotoksik mediatörler, glutamat toksititesi, hücre membranlarında serbest radikal oluşumu ve lipit peroksidasyonudur [5].

ASKY'nın etkin tedavisindeki gelişmeler, spinal kord yaralanmasına eşlik eden patofizyolojik değişiklikleri anlamamıza bağlıdır. İnsan spinal kordunun karmaşıklı̆̆ı, büyüklüğü ve kemik yapı ile korunmuş olması bizim akut travmaları iyi değerlendirmemizi zorlaştırmaktadır. Bu güne kadar sunulan yeni nörofizyolojik yöntemler ve görüntüleme teknikleri, insan akut spinal kord yaralanmasını belirlemede sınırlı güce sahiptir [6]. ASKY sonrası spinal decompresyonun zamanı ile ilgili birçok çelişkili bilgi bulunmaktadır [7-11]. ASKY'nın fizyopatolojisini anlamak için, spinal kord yaralanmalarında görülen kan akımı ve metabolik değişikliklerin deneysel hayvan modellerinde gösterilmesi gerekmektedir.

Spinal kord yaralanması olan hastalarda seksüel fonksiyonlar çok ciddi şekilde etkilenmektedir. Bu etkinin derecesi yaralanmanın şiddetine ve lokalizasyonuna bağlıdır [12]. Spinal kord yaralanması oluşan kişinin cinsiyeti de seksüel cevabın gelişimi açısından önemlidir ve özellikle erkeklerde oluşan seksüel problemlerle ilgili birçok çalışma yapılımıştır [12-15].

$\mathrm{Bu}$ çalışmanın amacı, deneysel spinal kord yaralaması sonrası erken cerrahi dekompresyonun motor fonksiyonlar ve korpus kavernozum fonksiyonu üzerine olan etkilerini araştırmaktır.

\section{Gereç ve yöntem}

\section{Grupların oluşturulması}

Çalışmada 21 adet 9-12 aylık, ortalama 2400 gr ağırlığında Yeni Zelanda tipi, erişkin erkek tavşan kullanıldı. Deneklere yapılacak işlemler konusunda Cumhuriyet Üniversitesi Tıp Fakültesi Hayvan Etik Kurulunun 01.04.2004/33 tarihli onayı alındı. Deneyler 
Cumhuriyet Üniversitesi Tip Fakültesi Deneysel Araştırma Laboratuvarı, Farmakoloji Laboratuvarı ve Patoloji Laboratuvarında gerçekleştirildi. Bütün invaziv işlemler, genel anestezi altında yapıldı.

Kontrol grubu ( $\mathrm{n}=5$ ) hayvanlara, herhangi bir cerrahi işlem uygulanmadan sakrifiye edildi ve izole edilen korpus kavernozum dokularının organ banyosunda, kasılma ve gevşeme yanıtlarına bakıldı. İkinci gruba (laminektomi grubu, $\mathrm{n}=6$ ), genel anestezi altında laminektomi yapıldı. Üçüncü gruba $(n=5)$ laminektomi sonrası anevrizma klipsi ile $15 \mathrm{sn}$ geçici kompresyon uygulanması, dördüncü gruba $(n=5)$ ise $1 \mathrm{dk}$ geçici kompresyon uygulandı [14]. İkinci, Üçüncü ve dördüncü gruplara post-operatif 1., 3.,5 ve 7. günler Modifiye Tarlov skoruna göre motor muayene yapıldı $[4,15]$. Bütün denekler 7. günde sakrifiye edilerek medulla spinalis ve korpus kavernozum doku örnekleri alındı. Korpus kavernozum dokularının kasıcı ve gevşetici maddelere verdikleri cevapları test edildi. Omurilikten alınan örnekler ise histopatolojik inceleme için patoloji laboratuvarına götürüldü.

\section{İzometrik ölçümler}

Tavşanlardan alınan korpus kavernozum dokuları uygun şekilde çevre dokularından arındırılarak temizlendi. Her bir hayvandan alınan dokudan dört adet düz kas şeridi elde edildi ve bu şeritler $10 \mathrm{~mL}$ 'lik su 1sıtmalı organ banyolarına yerleştirildi. Her bir şerit, eşit boyda olmak üzere $37^{\circ} \mathrm{C}^{\prime}$ da ssitılan Krebs-Bikarbonat solüsyonu (İçeriği: $\mathrm{NaC1}$ : $118 \mathrm{mM} / \mathrm{L}, \mathrm{KCl}: 4,7 \mathrm{mM} / \mathrm{L}, \mathrm{CaCl}_{2}: 2,5 \mathrm{mM} / \mathrm{L}, \mathrm{NaHCO}_{3}: 25 \mathrm{mM} / \mathrm{L}, \mathrm{MgSO}_{4}: 1,2 \mathrm{mM} / \mathrm{L}$, $\mathrm{KH}_{2} \mathrm{PO}_{4}: 1,2 \mathrm{mM} / \mathrm{L}$, glukoz: $11 \mathrm{mM} / \mathrm{L}$ ) içinde bir ucu cam organ askısına, diğer ucu ise 4/0 ipek ile Grass-FT 03 Force Displacement güç çevirgecine bağlandı. Dokular 2 gramlık ön gerilim altında her 15 dakikada bir yeni solüsyon ile yıkanarak, 1 saatlik dengelenmeye bırakıldı. Solüsyon $\% 95 \mathrm{O}_{2}$ ve $\% 5 \mathrm{CO}_{2}$ ile çalışma boyunca gazlandırıldı. $\mathrm{Bu}$ dengelenme süresinin sonunda şeritler, deney sırasında oluşması muhtemel olan spontan kasılmaları önlemek hem de kasılma yanıtlarının değerlendirilmesinde ölçüt olması amacı ile $124 \mathrm{mM} \mathrm{KCl}$ solüsyonu ile kasıldılar. Daha sonra yıkanan dokular kasıcı ve gevşetici maddelerin uygulanması için 30 dakika dinlenmeye bırakıldı. Korpus kavernozum dokusundaki sinüzoidal endotelin fonksiyonelliği, dokuların fenilefrin $\left(10^{-5}\right.$ M, Sigma) ile submaksimal konsantrasyonda kasıldıktan sonra karbakol ( $10^{-6} \mathrm{M}$, Sigma) ile gevşetilmesi ile doğrulandı.

Her dört gruptan da alınan korpus kavernozum dokusu ilaçlar verilmeden önce, dokuların fonksiyonelliğini test etmek amacıyla $124 \mathrm{mM} \mathrm{KCl}$ ile kastırıldı. $\mathrm{KCl}$ ile alınan kasılma yanıtları mg olarak grafiklendi. İzole korpus kavernozum preparatları, fenilefrin ile $\left(10^{-5}\right.$ M), submaksimal olarak kasıldıktan sonra karbakol, gevşeme yanıtları kümülatif olarak alındı. Her bir konsantrasyondaki gevşeme yanıtı dengeye eriştikten sonra bir üst konsantrasyona geçildi. Her 4 gruptaki gevşeme yanıtları fenilefrinin $\left(10^{-5} \mathrm{M}\right)$ oluşturduğu kasılma yanıtı üzerinde \% gevşeme olarak grafiklendi.

\section{Patolojik inceleme}

Patolojik inceleme, denekler sakrifiye edildikten sonra aynı insizyonla girilerek lezyon seviyesinin üst ve alt segmentindeki laminalara laminektomi yapıldı. Kök sinirler ve duranın bağları kesilerek medulla spinalis çıkarıldı. Lezyon seviyesinin proksimali, distali ve lezyon seviyesi olarak üç kısma ayrılarak kodlanıp \%10'luk formadehit solusyonuna kondu. \%10'luk formaldehit solusyonu ile tespit edilmiş ve rutin doku takibiyle hazırlanmış parafin bloklardan elde edilen örneklerden Hematoksilen-Eozin (H\&E) yöntemi ile preperatlar hazırland.

\section{Istatiksel yöntem:}

Kasılma ve gevşeme yanıtlarının istatistiksel analizleri metin içerisinde ortalama \pm standart sapma olarak sunuldu. Gruplar arasında fark olup olmadığı Kruskal-Wallis testi ile test edildi. İki grup arasındaki farkın anlamlılığı Mann-Whitney U testi ile araştırıldı ve $\mathrm{p}$ değerinin 0.05 'den küçük olması halinde fark anlamlı kabul edildi. Agonist ilaçların 
oluşturduğu maksimum yanıtın \%50'sini oluşturmak için gereken konsantrasyon (EC50) her bir deneyin log-konsantrasyon yanıt eğrilerinden elde edildi ve ortalama \pm standart sapma olarak gösterildi.

pD2 değerleri aşağıdaki formüle göre hesapland1.

pD2 $=\log \mathrm{A}-\log ($ Emax/EA-1 $)$

$\mathrm{A}=$ Agonist ilacin molarkonsantrasyonu

Emax=Agonist ilacın oluşturduğu maksimum etki

\section{Bulgular}

\section{Modifiye Tarlov skoru bulguları}

Deney grubu ve kontrol grubundaki denekler, 1., 3., 5., ve 7. günlerde Modifiye Tarlov yöntemi ile skorlandı [11]. Birinci gün gruplar arasındaki fark önemli bulunmuştur $(p<0,05)$. Gruplara ait değerler, ikişerli karşılaştırıldığında; kontrol grubu ve laminektomi grubu, kontrol grubu ve $15 \mathrm{sn}$ kompresyon grubu, kontrol grubu ve 60 sn kompresyon grubu arasinda farklilık anlamlı bulunurken $(\mathrm{p}<0,05)$, laminektomi grubu ve 15 sn kompresyon grupları arasında anlamlı fark bulunmamıştır $(\mathrm{p}>0,05)$. Üçüncü güne ait skor değerleri karşılaştırıldığında gruplar arasındaki fark anlamlı bulunmuştur $(p<0,05)$. Gruplara ait skor değerleri ikişerli karşılaştırıldığında kontrol grubu ve laminektomi, kontrol grubu ve 15 sn kompresyon grubu, kontrol grubu ve 60 sn kompresyon grubu, laminektomi grubu ve 15 sn kompresyon grubu, laminektomi grubu ve 60 sn kompresyon grubu arasinda fark anlamlı bulunurken $(\mathrm{p}<0,05) ; 15$ sn kompresyon grubu ve 60 sn kompresyon grubu arasında fark bulunmamıştır $(p>0,05)$. Beşinci gün gruplar arasındaki fark önemli bulunmuştur $(\mathrm{P}<0,05)$. Gruplara ait değerler, ikişerli karşılaştırıldığında kontrol ve laminektomi, kontrol ve 15 sn kompresyon, kontrol ve 60 sn kompresyon grupları arasında farklılık anlamlı bulunurken $(\mathrm{p}<0,05)$, laminektomi ve 15 sn kontrol grupları arasında anlamlı fark bulunmamıştır $(p>0,05)$. Yedinci güne ait skorlar karşılaştırıldığında ise gruplar arasındaki fark anlamlı bulunmuştur $(p<0,05)$. Gruplara ait skor değerleri ikişerli karşılaştırıldığında; kontrol grubu ve laminektomi grubu, kontrol grubu ve 15 sn kompresyon grubu, kontrol grubu ve 60 sn kompresyon grubu, laminektomi grubu ve 15 sn kompresyon grubu, laminektomi grubu ve kompresyon grubu, 15 sn kompresyon grubu ve 60 sn kompresyon grubu arasindaki farklar anlaml bulunmuştur $(\mathrm{p}<0,05)$ (Grafik 1).

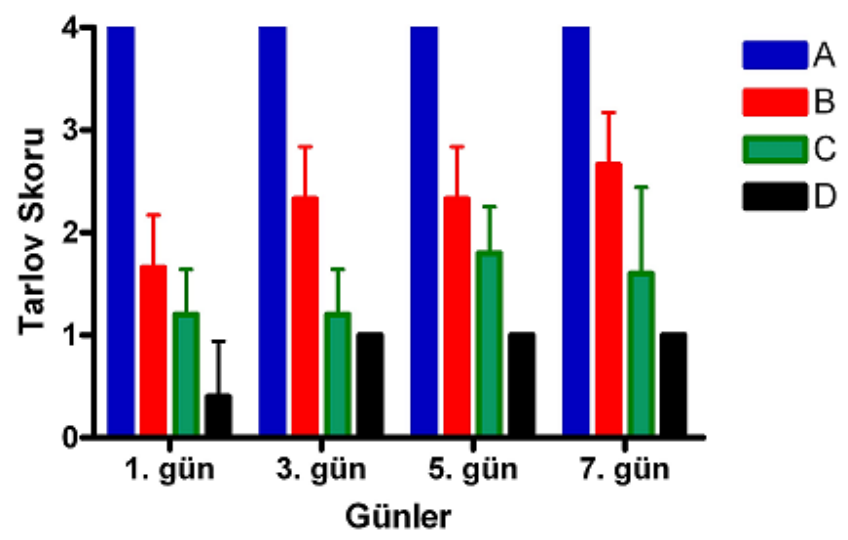

Grafik 1. Grupların 1., 3., 5 .ve 7. günler Modifiye Tarlov skorlarının gösterilmesi (Kontrol grubu (A), laminektomi grubu (B), 15 sn kompresyon grubu (C), 60 sn kompresyon grubu (D)). 


\section{Korpus akvernozum kasılma ve gevşeme yanıtları}

Kontrol ve laminektomili gruplarla karşılaştırıldığında 15 ve 60 sn lik kompresyon deney gruplarında, $\mathrm{KCl}$ kasılma yanıtları anlamlı bir farklılık göstermedi ( $>0,05)$ (Grafik 2). 15 ve 60 sn'lik kompresyonlu grupta maksimum gevşeme yanıtları istatistiksel olarak benzerdi bu gruplardaki maksimum gevşeme yanıtlanı gerek kontrol gerekse laminektomi grubuna göre anlamlı oranda azalmıştı $(\mathrm{p}<0,05)$. Laminektomi ve kontrol grubu karşılaştırıldığında maksimum gevşeme yanıtları arasında anlamlı fark bulunmadı $(\mathrm{p}>0,05)$ (Grafik 3). Karbakol ile elde edilen gevşeme yanıtları $\mathrm{E}$ maks ve $\mathrm{pD}_{2}$ değerleri üzerinden değerlendirildi Her dört grupta da $\mathrm{pD}_{2}$ değerleri benzerdi (Tablo 1).

Tablo 1. Gruplararası Emaks ve pD2 değerlerinin karşılaş̧ırılması (Kontrol grubu (A), laminektomi grubu (B), 15 sn kompresyon grubu (C), 60 sn kompresyon grubu (D).

\begin{tabular}{lllll}
\hline & A & B & C & D \\
\hline $124 \mathrm{mM} \mathrm{KCl}$ & & & & \\
\hline E maks (mg) & $2210 \pm 182$ & $2308 \pm 202$ & $2258 \pm 226$ & $2348 \pm 208$ \\
\hline Karbakol & & & & \\
\hline E maks (\%) & $84 \pm 4,0$ & $77,2 \pm 4,6$ & $52,7 \pm 4,3^{*}$ & $45,6 \pm 4,2^{*}$ \\
pD2 & $6,48 \pm 0,08$ & $6,26 \pm 0,07$ & $6,34 \pm 0,08$ & $6,26 \pm 0,06$ \\
\hline *Kontrol grubu ile karșlaștırıldı̆̆ında istatistiksel olarak anlamlı, $<0,05$
\end{tabular}

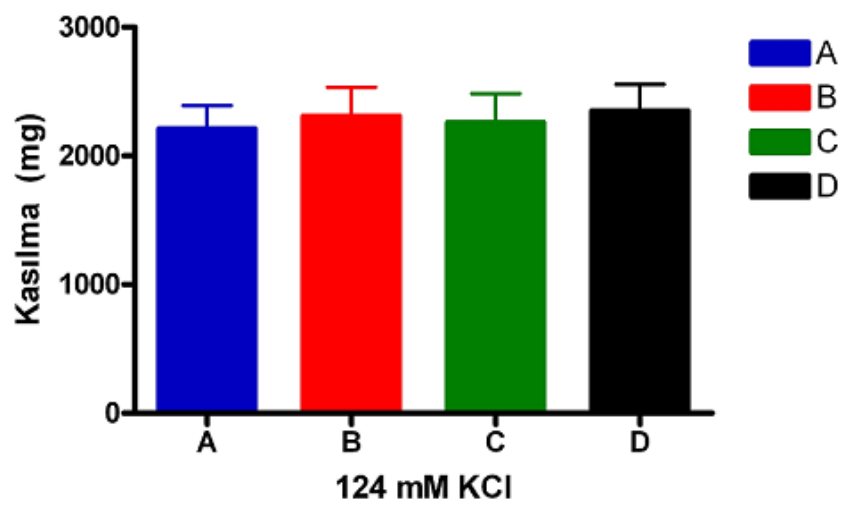

Grafik 2. İzole korpus kavernozum şerilerinde $124 \mathrm{mM}$ potasyum $\mathrm{KCl}$ Kasılma yanıtları. (Kontrol grubu (A), laminektomi grubu (B), 15 sn kompresyon grubu (C), 60 sn kompresyon grubu (D)).

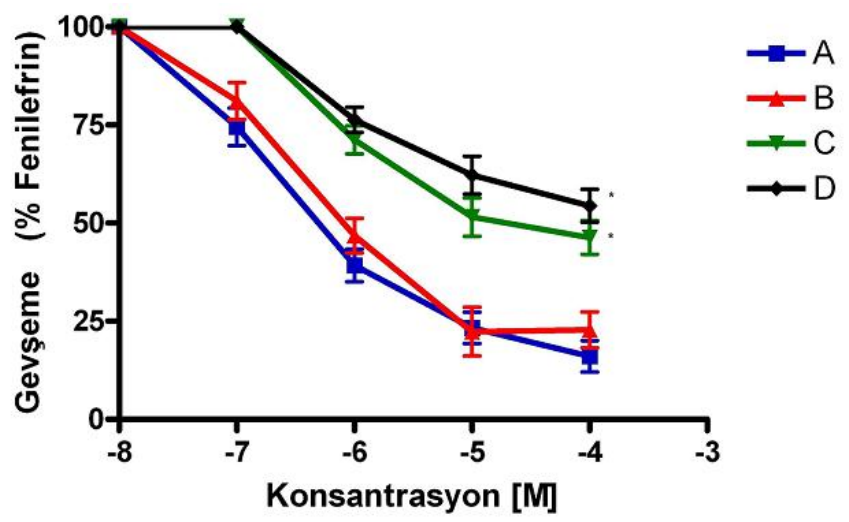

Grafik 3. Fenilefrin $\left(10^{-5} \mathrm{M}\right)$ ile kastırılmış izole korpus kavernozum şeritlerinde karbakol konsantrasyon yanıt eğrisi. (Kontrol grubu (A), laminektomi grubu (B), 15 sn kompresyon grubu (C), 60 sn kompresyon grubu (D)). 


\section{Patolojik değerlendirme sonuçları}

Gruplara ait H\&E boyalı preperatlların 1ş1k mikroskopisi ile incelenmesi sonucunda laminektomi grubunda ki deneklerde özellikle lezyonun proksimalinden alınan kesitlerde belirgin hiperemi, stoplazmik vakuolizasyonda artış ve yer yer kromatolizis görüldü.

15 saniye kompresyon grubunda lezyonun proksimalinde daha fazla olmak üzere yaygın kanama odakları, hiperemi, stoplazmik vakuolizasyon, perivasküler halo, kromatolizis görüldü. Lezyon seviyesinde stoplazmik eozinofili ve kromatolizis görüldü. Bu grupta lezyonun distalinden alınan kesitlerde gliozis, stoplazmik eozinfili, perinükleolar halo ve kromatolizis izlendi (Resim 1).

60 sn kompresyon grubunda lezyonun proksimalinden alınan kesitlerde yaygın nükleus kayb1, belirgin hiperemi, stoplazmik vakuolizasyon, stoplazmik eozinofili ve karyoreksis görüldü (Resim 2). Lezyon seviyesinde belirgin kanama alanları hiperemi, eozinofili ve kromatolizis görüldü. Lezyonun distalinde ise belirgin hiperemi nükleus kaybı, eozinofili ve kromatolizis izlendi (Resim 3).

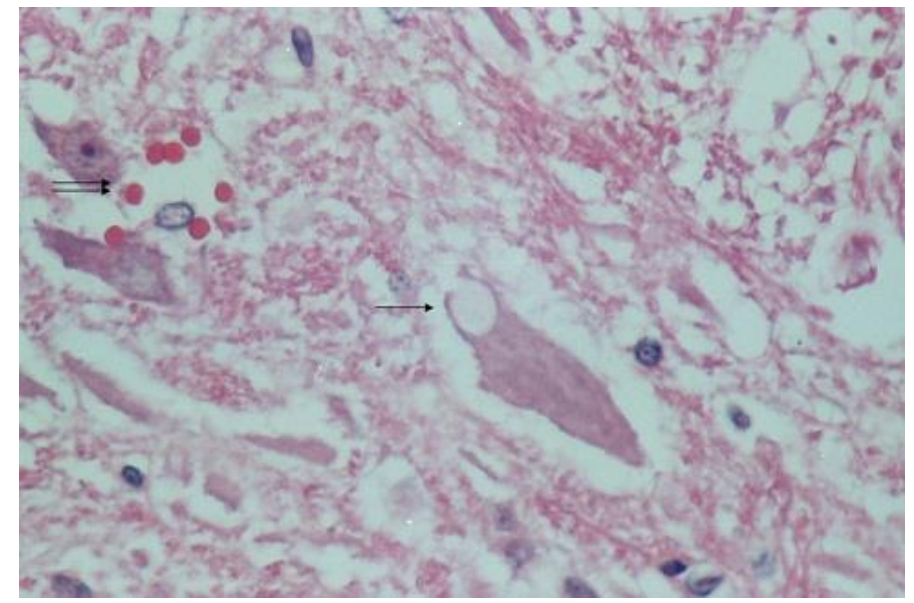

Resim 1. On beș sn kompresyon grubu-lezyon proksimali belirgin stoplazmik vakuolizasyon (ok) ve hiperemi (ikili ok) (H\&Ex50).

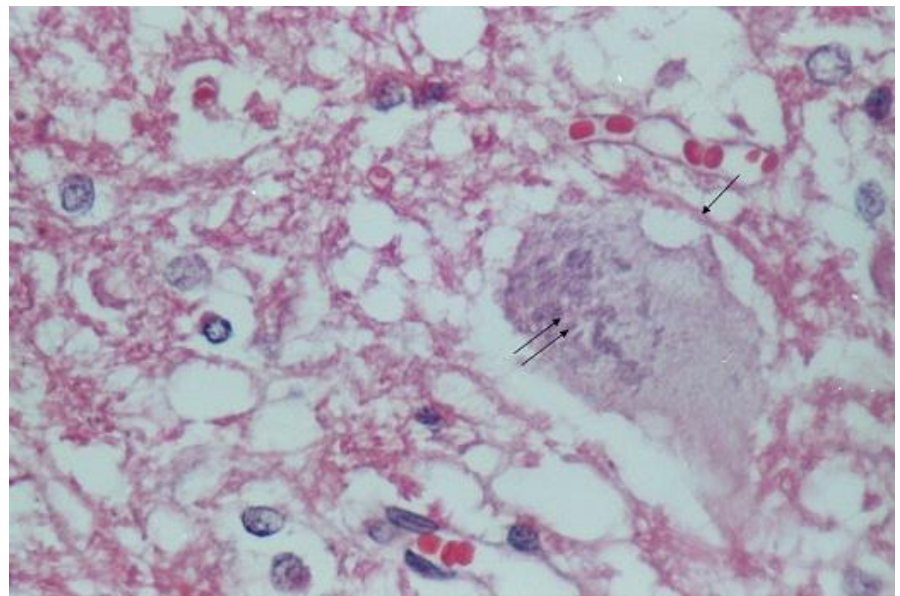

Resim 2. Altmış sn kompresyon grubu- lezyon proksimali stoplazmik vakuolizasyon (ok), karyoreksis (ikili ok) ve hiperemi (H\&Ex50). 


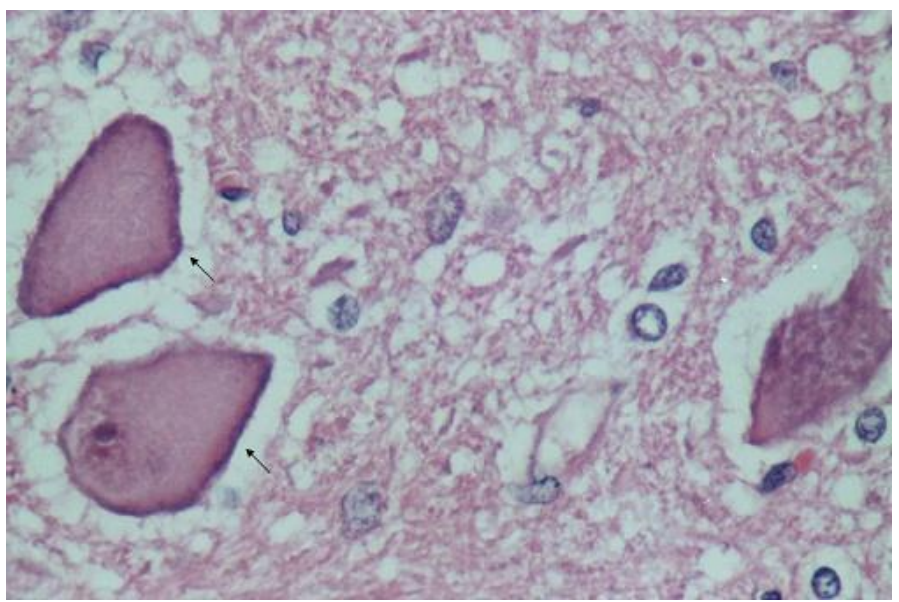

Resim 3. Altmış sn kompresyon grubu-lezyon proksimali eozinofili (H\&Ex25).

\section{Tartışma}

Spinal kord yaralanması tedavisinde temel amaç rezidüel nörolojik fonksiyonları korumak, sekonder yaralanmayı engellemek ve spinal kord stabilitesini sağlamaktır. Daha sonraki tedavilerde nörotropik faktor infüzyonu ve nöral doku transplantasyonu düşünülebilir ancak bundan önce sekonder zedelenme engellenmeli ve spinal kordun toparlanmasina yardımcı olunmalıdır [16].

Akut spinal kord yaralanmalarında, erken cerrahinin etkinliği de tartışmalıdır. Çoğu yazar erken cerrahi dekompresyon endikasyonu olarak progresif nörolojik defisit bulunmasını göstermektedir [17]. Spinal cerrahide genel olarak kabul edilmiş görüşe göre önden kemik fragmanının basısına bağlı parsiyel nörolojik yaralanması olan burst kırıklarında ne kadar erken dekompresyon yapilırsa nörolojik tablodaki düzelme o oranda artacaktır. $\mathrm{Bu}$ süre genel olarak ilk 24-48 saat olarak kabul edilir. Bu konuda klinik prospektif çalışmalar etik yönden yapılamamaktadır [18-21].

$\mathrm{Bu}$ çalışmada, ASKY da erken cerrahi dekompresyonun etkinliğini deneysel hayvan modeli üzerinde incelemeye çalıştık. Modifiye Tarlov skoruna bakıldığında gruplar arası fark anlamlı bulundu. Korpus kavernozumun karbakol ile gevşeme yanıtlarına bakıldığında 15 ve 60 sn lik kompresyonlu grupta maksimum gevşeme yanıtları istatistiksel olarak benzer idi ve bu gruplardaki maksimum gevşeme yanıtları gerek kontrol gerekse laminektomili gruba göre anlamlı oranda azalmıştı. Laminektomi ve kontrol grubu karşılaştırıldığında maksimum gevşeme yanıtları arasında anlamlı fark bulunmadi. Her dört grupta da $\mathrm{pD}_{2}$ değerleri benzerdi.

$\mathrm{Bu}$ sonuçlar genel olarak değerlendirildiğinde, modifiye Tarlov motor skorlamasına göre gruplar arasında anlamlı fark olması, laminektomi sırasında da spinal korda minimal hasar verdiğimizi ve kullandığımız deneysel modelde başarılı olduğumuzu göstermektedir. Bu grubu diğer kompresyon grupları ile karşılaştırdığımızda 15 sn ve 60 sn kompresyon gruplarına göre anlamlı fark mevcuttu. Buradan çıkan sonuç, deney modelimizde kompresyon dişında korda minimal hasar verdiğimiz şeklindeydi. Histopatolojik bulgular ile korpus kavernozumun kasılma ve gevşeme yanıtları bulguları da bunu desteklemekteydi.

On beş saniye ve altmış sn kompresyon gruplarında, Modifiye Tarlov Skoruna göre istatistiksel olarak anlamlı fark olması, erken dekompresyonun parsiyel nörolojik defisitli akut spinal kord yaralanmasında erken cerrahinin motor düzelme açısından önemli olduğunu göstermektedir.

Çalışmamızda korpus kavernozum düz kas şeritlerinde, $\mathrm{KCl}$ kasılma yanıtları değişmedi. $\mathrm{Bu}$ durum kompresyon sonunda, kasların kasılma fonksiyonunda bir değişiklik 
olmadığını gösterir. Korpus kavernozum dokusunda karbakole bağlı olan gevşeme yanıtları, kompresyonlu gruplarda kontrol ve laminektomi gruplarına göre anlamlı ölçüde azalmıştır. Bu olay muskarinik reseptörlerdeki bir azalmaya ve/veya bu reseptörlerin uyarılmasına ikincil, endotelden nitrik oksit (NO) salınımındaki bir azalmaya bağlı olabilir. Kompresyonlu gruplarda karbakolle olan gevşeme yanıtları, devam ettiği için bu tür hastalarda erektil disfonksiyon için fosfodiesteraz tip V inhibitörleri faydalı olabilir [22].

Korpus kavernozumun kasılma yanıtlarının sonuçlarına göre 15 ve 60 sn kompresyon grupları arasında fark bulunamamıştı. Bu bize ilk bakışta erken cerrahi dekompresyonun korpus kavernozum dokuları üzerine olumlu etkisinin olmadığını düşündürmektedir. Fakat laminektomi grubu ile 30 ve 60 sn kompresyon grupları arasında anlamlı fark olduğu, laminektomi grubunda da kord hasarının bulunduğu göz önünde bulundurulursa, daha az hasar görmüş laminektomi grubunun korpus kavernozumun gevşeme fonksiyonları açısından daha iyi durumda olduğunu ve erken kompresyonun korpus kavernozum fonksiyonları açısından önemli olabileceğini söyleyebiliriz. Ancak bu sonuca varabilmek için daha düşük kapama gücü olan klipslerle ve daha az süreli kompresyon süresi oluşturarak deneysel çalışmalar yapılmalıdır.

Histopatolojik inceleme sonucunda, laminektomi grubunda da 15 ve 60 sn kompresyon grubundakine benzer bir takım patolojik değişiklikler görüldü. Sadece laminektomi yapılan deneklerin spinal kordunda da minimal hasar oluştu. Farooque de farelerde weight-drop tekniğiyle oluşturduğu spinal kord yaralanmasında, 2 haftada oluşturduğu laminektomi grubunda benzer sonuçlar almıştı [23].

Sonuç olarak, akut spinal kord yaralanmasında erken cerrahi dekompresyonun etkinliğini araştırdığımız bu model ile spinal kord yaralanmasında seksüel disfonksiyonunun tedavisinde kullanılması düşünülen ilaçların in vitro ortamda ayrıntılı olarak araştırılması mümkün olabilir. Akut spinal kord yaralanmasında erken cerrahi dekompresyon motor iyileşme yönünden faydalı olabilir ve korpus kavernozum fonksiyonları açısından olumlu etkiler yapabilir. Ayrıca, akut spinal kord yaralanması geçiren hastalarda erektil disfonksiyon problemi fosfodiesteraz V inhibitörleri gibi ilaçlarla çözülebilir.

\section{Kaynaklar}

1. Teng YD, Mocchetti I, Taveira-DaSilva AM, Gillis RA, Wrathall JR. Basic fibroblast growth factor increases long-term survival of spinal motor neurons and improves respiratory function after experimental spinal cord injury. J Neurosci 1999; 19: 7037-47.

2. Bracken MB, Shepard MJ, Collins WF, Holford TR, Young W, Baskin DS, Eisenberg HM, Flamm E, Leo-Summers L, Maroon J, Marshall LF, Perot PL, Piepmeier J, Sonntag VKH, Wagner FC, Wilberger JE, Winn HR. A randomized, controlled trial of methylprednisolone or naloxone in the treatment of acute spinal-cord injury. Results of the Second National Acute Spinal Cord Injury Study. N Engl J Med 1990; 322: 1405-11.

3. Kurtzke JF. Epidemiology of spinal cord injury. Neurol Neurocir Psiquiatr 1977; 18: $157-91$.

4. Khan T, Havey RM, Sayers ST, Patwardhan A, King WW. Animal models of spinal cord contusion injuries. Laboratory Animal Science 1999; 49: 161-72.

5. Centers for Disease Control (CDC). Acute traumatic spinal cord injury surveillance--United States, 1987. MMWR Morb Mortal Wkly Rep 1988 May 13; 37: 285-6.

6. Rothman RH, Simeone FA. Spine in: Martinez A, Gren BA, Bunge RP editors: Experimental spinal cord injury: patophysology and treatment 3rd ed. Philadelphia: WB Saunders Company; 1992; pp: 1247-76.

7. Raslan AM, Nemecek AN. Controversies in the surgical management of spinal cord injuries. Neurol Res Int 2012; 2012: 417834. 
8. Wilson JR, Singh A, Craven C, Verrier MC, Drew B, Ahn H, Ford M, Fehlings MG. Early versus late surgery for traumatic spinal cord injury: the results of a prospective Canadian cohort study. Spinal Cord 2012; 50: 840-3.

9. Jones CF, Cripton PA, Kwon BK. Gross morphological changes of the spinal cord immediately after surgical decompression in a large animal model of traumatic spinal cord injury. Spine (Phila Pa 1976) 2012; 37: E890-9.

10. Fehlings MG, Vaccaro A, Wilson JR, Singh A, W Cadotte D, Harrop JS, Aarabi B, Shaffrey C, Dvorak M, Fisher C, Arnold P, Massicotte EM, Lewis S, Rampersaud R. Early versus delayed decompression for traumatic cervical spinal cord injury: results of the Surgical Timing in Acute Spinal Cord Injury Study (STASCIS). PLoS One 2012; 7: e32037.

11. Bissonette DJ. Sorting out spinal cord syndromes, J Am Acad Phys Assist 1988; 1: 4-15.

12. Bors E, Comarr AE. Neurological disturbances of sexual function with special reference to 529 patients with spinal cord injury. Urol Surv 1960; 110: 191-222.

13. Phelps G, Brown M, Chen J, Dunn M, Lloyd E, Stefanick ML, Davidson JM, Perkash I. Sexual experience and plasma testosterone levels in male veterans after spinal cord injury. Arch Phys Med Rehabil 1983; 64: 47-52.

14. Öztemür Z, Tezeren G, Bağcıvan I, Saraç B, Durmuş N, Eğilmez R. Evaluation of urinary bladder function after acute spinal cord injury: an experimental study. Eklem Hastalık Cerrahisi 2010; 21: 110-5.

15. Tarlov IM, Klinger H, Vitale S. Spinal cord compression studies. I. Experimental techniques to produce acute and gradual compression. AMA Arc Neourol Psychiat 1953; 70: 813-9.

16. Ducker TB, Lucas JT, Wallace CA. Recovery from spinal cord injury. Neurosurg 1983; 30: 495-513.

17. Carlson GD, Minato Y, Okada A, Gorden CD, Warden KE, Barbeau JM, Biro CL, Bahnuik E, Bohlman HH, Lamanna JC. Early time-dependent decompression for spinal cord injury: vascular mechanisms of recovery. J Neurotrauma 1997; 14: $951-62$.

18. Chapman JR, Anderson PA. Thoracolumbar spine fractures with neurologic deficit. Orthop Clin North Am 1994; 25: 595-612.

19. Jarmundowicz W, Lawicki B, Orkisz S. The effect of prolonged spinal cord compression on the extent of morphological changes in experimental spinal cord injury in rabbits. Neurol Neurochir Pol 1997; 31: 1177-88.

20. Jarmundowicz W, Tosik D, Chlebiński J, Górkiewicz Z. The effect of early decompression on the extent of changes in spinal cord microcirculation in experimental traumatic injury to the cord in rabbits. Neurol Neurochir Pol 1997; 31: 1167-75.

21. Canale ST. Campbell's Operative Orthopaedics.in: Leventhal MR editor: Fractures, dislocation and fracture-dislocations of spine.9th ed. St Lois; Mosby; s $1998 ; 2749$.

22. Kelley M. Can viagra help disabled men-its safe. Accent on Living 1998; 3: 44-7.

23. Farooque M. Spinal cord compression injury in the mouse: presentation of a model including assessment of motor dysfunction. Acta Neuropathol 2000; 100: 13-22. 